\title{
GENETIC ANALYSES OF Rhizoctonia solani ISOLATES FROM Phaseolus vulgaris GROWN IN THE ATLANTIC RAINFOREST REGION OF SÃO PAULO, BRAZIL
}

\author{
LYNDEL W. MEINHARDT ${ }^{1 *}$, NELSON A. WULFF ${ }^{2}$, CLÁUDIA M. BELLATO $^{1}$ \& SIU M. TSAI ${ }^{1}$
}

\begin{abstract}
${ }^{1}$ Laboratório Biologia Celular e Molecular, Centro de Energia Nuclear na Agricultura, Universidade de São Paulo, Av. Centenário 303, Cx. Postal 96, CEP 13400-970, Piracicaba, SP, fax (019) 3429-4610, e-mail: lyndel@ cena.usp.br; ${ }^{2}$ Universidade de São Paulo, Escola Superior de Agricultura "Luiz de Queiroz", Departamento de Entomologia, Fitopatologia e Zoologia Agrícola, Av. Pádua Dias, 11, CEP 13418-900, Piracicaba, SP, fax (019) 3429-4839
\end{abstract}

(Accepted for publication on 23/01/2002)

Corresponding Author: Lyndel W. Meinhardt

MEINHARDT, L.W., WULFF, N.A., BELLATO, C.M. \& TSAI, S.M. Genetic analyses of Rhizoctonia solani isolates from Phaseolus vulgaris grown in the Atlantic Rainforest Region of São Paulo, Brazil. Fitopatologia Brasileira 27:259-267. 2002.

\begin{abstract}
Rhizoctonia solani isolates obtained from common beans (Phaseolus vulgaris) grown in the mountainous Atlantic Rainforest (Mata Atlântica) region of São Paulo, Brazil, were analyzed to determine their genetic diversity using internal transcribed spacer (ITS), microsatellite and telomere sequence-based PCR primers. Restriction digestion of the ITS1/5.8S/ITS2 ribosomal regions yielded unique banding patterns specific for AG4 and its subgroups. The ITS restriction digestion (ITS/RFLP), telomere and microsatellite primers

identified five to 11 genotypes within the isolates of $R$. solani. While all isolates were pathogenic on beans, there was no correlation found between genotypic differences and pathogenicity. The different PCR primers revealed a number of isolates that were genetically similar. Some of these genetic groups were supported by more than one of the primers utilized in this study, thus confirming their relationship.

Additional keywords: Mata Atlântica, genetic biodiversity, soil-borne fungi, ITS, telomere.
\end{abstract}

\section{RESUMO \\ Análise genética de isolados de Rhizoctonia solani de Phaseolus vulgaris da região da Mata Atlântica de São Paulo, Brasil}

A diversidade genética de 18 isolados de Rhizoctonia solani de feijoeiro (Phaseolus vulgaris) cultivado na Mata Atlântica de São Paulo, Brasil foi avaliada através da análise do espaçadores transcritos internos (ITS), microssatélites e iniciadores ("primers") específicos para sequências teloméricas. A análise de restrição da região ribossomal ITS1/5,8S/ITS2 produziu um padrão de bandas específico para o grupo de anastomose 4 (GA 4) e seus subgrupos. O padrão obtido com ITS/RFLP, microsatélites e os iniciadores teloméricos permitiram identificar cinco a 11 genótipos entre os isolados de R. solani. Enquanto todos os isolados foram patogênicos em feijoeiro, não houve correlação entre patogenicidade e diferenças genotípicas. Os diferentes iniciadores para PCR revelaram que muitos isolados são geneticamente similares, análise esta que pode ser confirmada por mais de um conjunto de iniciadores, fortalecendo a relação deste agrupamento.

\section{INTRODUCTION}

The Mata Atlântica or the Atlantic Rain forest of Brazil is one of the most threatened tropical ecosystems in the world (Mori, 1989). This ecosystem is known for its extreme biodiversity of plant, amphibian and animal species (www.ambiente.sp.gov.br \& www.nybg.org/bsci/res/una. $\mathrm{html}$ ). Within this region, many small landholders intercrop corn (Zea mays L.) and common beans (Phaseolus vulgaris L.). The bean production is limited because of the poor acid soils, extreme slopes, heavy rainfall (the latter two combine to promote erosion) and plant diseases that limit production. After one or two plantings, these areas are abandoned for

\footnotetext{
*Current address of Lyndel W. Meinhardt is Laboratório de Genômica e Expressão, Departamento de Genética e Evolução, Instituto de Biologia/UNICAMP, Cx. Postal 6109, 13083-970 Campinas, SP, lyndel@lge.ibi.unicamp.br
}

other locations due to decreasing yields. More often than not, the new locations are forested or in a state of regenerating forest (areas that have been abandoned for five to seven years where many young primary tree species are established), which must be cleared, burned and tilled prior to planting. Due to the multifaceted interactions associated with this environment, it was decided to survey the genetic diversity of the soilborne plant pathogenic fungi that constitutes one of the major causes of limited bean production in the region.

This genetic diversity study was part of a four-yearsustainable-field-study. It was begun to evaluate conditions that limit bean production and to gather information to better understand the circumstances and restrictions that exist in this region. Of the economically important soilborne-fungal pathogens [Rhizoctonia solani Kühn, Fusarium solani (Mart.) Sacc., F. oxysporum Schlecht. f. sp. phaseoli Kendrick and Snyder and Sclerotium rolfsii Sacc.] observed causing disease 


\section{L.W. Meinhardt et al.}

in the field on P. vulgaris, R. solani was chosen for this study. Rhizoctonia solani [Thanatephorus cucumeris (Frank) Donk] is a complex soil-borne fungal pathogen made up of divergent populations that causes disease on a wide variety of cultivated plants in Brazil (Bolkan \& Ribeiro, 1985). These divergent populations have been identified and classified based on the anastomosis behavior of vegetative hyphal fusions (Carling et al., 1988). While anastomosis groups or AGs are an accepted means of grouping $R$. solani, the genetic and functional bases for the anastomosis reactions are still unknown. At present count, some 13 AGs and numerous subgroups are recognized (Carling et al., 1988; Carling, 1996; Carling et al., 1999).

Rhizoctonia solani is responsible for both leaf blights and root rots in common bean in Brazil, and all of the isolates of $R$. solani taken from leaves and roots of common bean belong to either AG4 or AG1 (Bolkan \& Ribeiro 1985). In the aforementioned study, no attempt was made to differentiate the isolates into their respective subgroups (Bolkan \& Ribeiro, 1985).

With the advent of molecular techniques, genetic diversity studies of fungal pathogens are possible. Most of the information pertaining to the genetic diversity of $R$. solani comes from Europe, Japan and North America (Kuninaga \& Yokosawa, 1984; Vilgalys \& Gonzalez, 1990; Liu \& Sinclair, 1993; Boysen et al., 1996; Keijer, et al., 1996; Kuninaga et al., 1997)

In this study, we used PCR-based analyses to determine individual genotypes of $R$. solani from the Brazilian Atlantic rainforest region located in the state of São Paulo. The purpose of this study was to determine the number and kinds of genotypes found in the field. Along with genotypic analysis, each isolate was evaluated for its ability to cause disease in four different plant species to see if genotype could be correlated with this particular trait.

\section{MATERIAL AND METHODS}

\section{Fungal Isolations and Storage}

Isolates of $R$. solani were obtained from symptomatic bean plants or infected seeds from five sites near Cunha, SP - Brazil. The five sites were part of a sustainable farming experimental project. All five sites were located within a 30$\mathrm{km}^{2}$ region. The sites were divided into 12 subplots/ treatments of $4 \mathrm{~m}^{2}$. Symptomatic plants were removed from the subplots. Roots and stems were surface disinfected by washing in $70 \%$ ethanol for $5 \mathrm{~min}$ followed by $5 \mathrm{~min}$ in $5 \%$ Clorox bleach. The tissues were rinsed five times with sterile water and placed onto sterile filter paper to dry in a flow hood. Tissue segments were plated onto potato dextrose agar (PDA) medium containing $50 \mu \mathrm{g} / \mathrm{ml}$ of Kanamycin. The plates were overlaid with a layer of water agar (WA), thus embedding the tissues. Fungal mycelia that grew through the top agar were examined microscopically and Rhizoctonia-like fungi were transferred to new plates. Rhizoctonia-like fungi all possessed the following traits: dolipore septa, branching near the distal septum of cells in young vegetative hyphae, constriction at the base of the branching, formation of a septum in the branch near the point of origin, and brown pigmentation (Parmeter \& Whitney, 1970). A single mycelial tip was isolated from plate cultures to obtain a pure culture. Harvested seeds were also tested for fungal infection via surface disinfecting and plating onto WA. Rhizoctonia-like fungi were transferred to PDA plates to obtain pure cultures.

The pure cultures were grown, stained, and viewed according to Meinhardt et al. (2001). Cultures that were found to be multinucleated were considered $R$. solani, while binucleate Rhizoctonia-like fungi were considered to be isolates of Ceratobasidium spp.

Cultures were maintained at $28{ }^{\circ} \mathrm{C}$ on PDA or malt extract agar (MEA) amended with $2 \mu \mathrm{M}$ thiamine. For longterm storage, the cultures were stored on MEA slants covered with mineral oil. The acronym CARS (CEN $\underline{A} \underline{R}$ hizoctonia solani) was used to designate the isolates in our collection (Table 1).

\section{Nuclear Condition}

The number of nuclei per hyphal cell was determined according to the procedure described by Meinhardt et al. (2001). An epi-fluorescent microscope (Olympus BX40 with a BX-FLA fluorescence attachment) was used to observe the nuclei.

\section{Anastomosis grouping}

Hyphal anastomosis or anastomosis grouping (AG) can be a key indicator of somatic and vegetative compatibility between isolates and was conducted by pairing unknown isolates with known tester strains according to standard procedures (Carling et al., 1988). The anastomosis tester isolates used in this study are listed in Table 2, and were obtained from Don Carling, University of Alaska, USA.

\section{Pathogenicity Tests}

Pathogenicity testing and root damage assessments of the isolates were carried out according to Carling et al. (1999). The only modification was that testing was conducted at 28 ${ }^{\circ} \mathrm{C}$ instead of $21{ }^{\circ} \mathrm{C}$. Isolates of $R$. solani were tested for pathogenic potential on common beans 'Carioca 80SH', tomatoes (Lycopersicon esculentum Mill.) 'Débora', bell peppers (Capsicum annuum L.) 'Magali', and soybeans (Glycine max L.) 'EMB 48'. Each test consisted of three plates with six seeds per plate for each isolate. All experiments were repeated at least twice. Root damage assessment scale was 0 = no damage, 1 = minor discoloration of hypocotyl, 2 = discoloration plus small necrotic lesions ( $<1 \mathrm{~mm}$ in diameter) on hypocotyl, 3 = discoloration with large necrotic lesions ( $1 \mathrm{~mm}$ or larger in diameter) on hypocotyl, $4=$ death of the seedling.

\section{DNA Extraction}

A CTAB DNA extraction protocol was used to acquire 
Genetic analyses of Rhizoctonia solani isolates from Phaseolus vulgaris grown...

TABLE 1 - Brazilian field isolates of Rhizoctonia solani used in this study

\begin{tabular}{|c|c|c|c|c|c|}
\hline AG & Subgroup & Isolate Id. & Origin (Site ${ }^{+}$) & Host & Collector/Supplier \\
\hline 4 & HG-I & CARS2 & Cunha, SP (OP) & Phaseolus vulgaris & L. W. Meinhardt \\
\hline 4 & HG-I & CARS3 & Cunha, SP (OP) & P. vulgaris \# & L. W. Meinhardt \\
\hline 4 & HG-I & CARS4 & Cunha, SP (OP) & P. vulgaris $\#$ & L. W. Meinhardt \\
\hline 4 & HG-I & CARS5 & Cunha, SP (OP) & P. vulgaris $\#$ & L. W. Meinhardt \\
\hline 4 & HG-I & CARS6A* & Cunha, SP (JE) & P. vulgaris $\#$ & L. W. Meinhardt \\
\hline 4 & HG-I & CARS6B ${ }^{*}$ & Cunha, SP (JE) & P. vulgaris \# & L. W. Meinhardt \\
\hline 4 & HG-I & CARS7 & Cunha, SP (DL) & P. vulgaris \# & L. W. Meinhardt \\
\hline 4 & HG-I & CARS8 & Cunha, SP (DL) & P. vulgaris $\#$ & L. W. Meinhardt \\
\hline 4 & HG-I & CARS11 & Cunha, SP (SL) & P. vulgaris $\#$ & L. W. Meinhardt \\
\hline 4 & HG-I & CARS19 & Cunha, SP (SL) & P. vulgaris $\#$ & L. W. Meinhardt \\
\hline 4 & HG-I & CARS20 & Cunha, SP (SL) & P. vulgaris \#\# & L. W. Meinhardt \\
\hline 4 & HG-I & CARS21 & Cunha, SP (SL) & P. vulgaris \#\# & L. W. Meinhardt \\
\hline 4 & HG-I & CARS22A** & Cunha, SP (SL) & P. vulgaris \#\# & L. W. Meinh ardt \\
\hline 4 & HG-I & CARS22B ${ }^{* * *}$ & Cunha, SP (SL) & P. vulgaris \#\# & L. W. Meinhardt \\
\hline 4 & HG-I & CARS22C ${ }^{* * *}$ & Cunha, SP (SL) & P. vulgaris \#\# & L. W. Meinhardt \\
\hline 4 & HG-I & CARS22D $^{* *}$ & Cunha, SP (SL) & P. vulgaris \#\# & L. W. Meinhardt \\
\hline 4 & HG-I & CARS23 & Cunha, SP (SL) & P. vulgaris \#\# & L. W. Meinhard t \\
\hline 4 & HG-I & CARS24 & Cunha, SP (SL) & P. vulgaris $\#$ & L. W. Meinhardt \\
\hline
\end{tabular}

${ }^{1} \mathrm{OP}, \mathrm{JE}, \mathrm{DL}$ and SL refer to the experimental site where the isolates were obtained from within the Cunha, SP region. HG-I and HG-II represent subgroup designations within the anastomosis group 4. AG stands for anastomosis group.

* isolates taken from the same plant

** isolates taken from same subplot - adjacent plants

\# P. vulgaris commercial variety Carioca $80 \mathrm{SH}$

\#\# P. vulgaris landrace variety Serra Azul

DNA from the fungal isolates. Fungal isolates were grown in $20 \mathrm{ml}$ of liquid medium $\left(4 \mathrm{~g} \mathrm{l}^{-1}\right.$ of malt extract broth (Merck) or $1 / 4$ MYEDP medium (4.75 g malt extract, $0.5 \mathrm{~g}$ yeast extract, $0.75 \mathrm{~g}$ dextrose, $0.45 \mathrm{~g}$ peptone, $500 \mathrm{mM}$ thiamine in a final volume of $11, \mathrm{pH} 5.6$ ). Five to six 0.5 $\mathrm{cm}^{2}$ agar blocks of each isolate were used to inoculate liquid medium. The cultures were incubated for four to five days at $28{ }^{\circ} \mathrm{C}$. The mycelia were centrifuged and washed once in sterile water and twice in $500 \mathrm{mM} \mathrm{NaCl}_{2}$ and $50 \mathrm{mM}$ EDTA $\mathrm{pH}$ 8.0. The mycelia were blotted dry and macerated in liquid nitrogen with $2800 \mu \mathrm{l}$ of DNA extraction buffer [1.0\% CTAB, $0.5 \mathrm{M} \mathrm{NaCl}_{2}, 69 \mathrm{mM}$ EDTA pH 8.0, $34 \mathrm{mM}$ Tris pH 8.0, $0.05 \% \mathrm{~N}$-lauryl sarcosine, $1 \% \mathrm{SDS}$, and $0.009 \% \beta$ mercaptoethanol]. Twenty $\mu$ l of proteinase $\mathrm{K}\left(20 \mathrm{mg} \mathrm{l}^{-1}\right)$ was added and the solution was incubated at $55^{\circ} \mathrm{C}$ for $2 \mathrm{~h}$. After incubation, the solution was centrifuged for $10 \mathrm{~min}$ at 12000 $g$ and phenol/chloroform extracted. DNA was precipitated in 0.8 volumes of isopropanol, centrifuged, and washed with $70 \%$ ethanol, dried, resuspended in $100 \mu \mathrm{l}$ of sterile water and stored at $4{ }^{\circ} \mathrm{C}$.

TABLE 2 - Rhizoctonia solani AG tester isolates used in this study

\begin{tabular}{|c|c|c|c|c|c|}
\hline AG & $\begin{array}{c}\text { Subgroup } \\
\text { designation }\end{array}$ & Isolate Id. & Origin & Host/Subst & Collector/Supplier \\
\hline 1 & $1 \mathrm{~A}$ & $\mathrm{CSKa}$ & Japan & Oryza sativa L. & S. Kuninaga \\
\hline 1 & $1 \mathrm{~B}$ & SFBV-1 & Japan & Beta vulgaris L. & S. Kuninaga \\
\hline 1 & $1 \mathrm{C}$ & M43 & Quebec, Canada & Pinus resinosa L. & N. Anderson \\
\hline 2 & 1 & F56L & Alaska, USA & Solanum tuberosum L. & D. Carling \\
\hline 2 & 2-IV & DR G-02 & Dominican Republic & Phaseolus vulgaris & G. Godoy-Lutz \\
\hline 2 & 3 & R-3 & Japan & Glycine $\max$ & S. Kuninaga \\
\hline $\mathrm{BI}$ & - & AI 1-4 & Japan & soil & S. Kuninaga \\
\hline 3 & $\mathrm{P}$ & SCL24 & Alaska, USA & S. tuberosum & D. Carling \\
\hline 4 & HG-I & AH-1 & Japan & Arachis hypopaea L. & S. Kuninaga \\
\hline 4 & HG-II & RR5-2 & Japan & B. vulgaris & S. Kuninaga \\
\hline 5 & - & ST-6-1 & Japan & S. tuberosum & A. Ogoshi \\
\hline 6 & HG-1 & OHT 1-1 & Japan & soil & S. Kuninaga \\
\hline 6 & GV & HN1-1 & Japan & soil & S. Kuninaga \\
\hline 7 & - & 1556 & Japan & soil & S. Kuninaga \\
\hline 8 & ZG 1-1 & CB-01 & Oregon, USA & $?$ & R. Smiley \\
\hline 9 & $\mathrm{TP}$ & F57M $^{*}$ & Alaska, USA & soil & D. Carling \\
\hline 9 & $\mathrm{TX}$ & S9R1 ${ }^{* *}$ & Alaska, USA & soil & D. Carling \\
\hline
\end{tabular}




\section{Molecular analysis}

PCR annealing temperatures ranged from $42^{\circ} \mathrm{C}$ to 50 ${ }^{\circ} \mathrm{C}$ depending on the primers used (note conditions for each specific primer listed below). All reactions were allowed to complete 35 cycles and utilized 1 unit of Taq DNA polymerase per reaction (Gibco/BRL or Promega). Magnesium chloride concentrations were $2.5 \mathrm{mM}$, while standard concentrations of DNA (100 ng), dNTPs $(400 \mu \mathrm{M})$ and primers $(200 \mathrm{pM})$ were used. All reactions were hot started at $92^{\circ} \mathrm{C}$ for $10 \mathrm{~min}$, and following the final cycle, all reactions were subjected to a $10 \mathrm{~min}$ cycle at $72{ }^{\circ} \mathrm{C}$ before ending the reaction. All reactions and/or digestions were repeated at least three times to ensure the reproducibility of the results.

\section{ITS Analysis}

The ITS1, ( ${ }^{\prime}$ TCC GTA GGT GAA CCT GCG $\mathrm{G}^{3}$ ) and ITS 4 primers, ( ${ }^{5}$ TCC TCC GCT TAT TGA TAT GC $^{3}$ ) described by White et al. (1990) were used at an annealing temperature of $50^{\circ} \mathrm{C}$. Primers were used in combinations to amplify a product of approximately $700 \mathrm{bp}$ for the ITS1/ITS4, which included both ITS regions and the 5.8S gene. To observe differences within this amplified region, the amplicons were digested with restriction enzymes, thus producing ITS-RFLPs (Liu \& Sinclair, 1993; Keijer et al., 1996).

Prior to digestion, a $10 \mu \mathrm{l}$ aliquot of each PCR product was analyzed via agarose gel electrophoresis in $0.5 \mathrm{X}$ TBE to verify the reaction and to check for contamination. The remainder of the PCR products was alcohol precipitated overnight $(0.1 \mathrm{X}$ volume $3 \mathrm{M}$ sodium acetate $\mathrm{pH} 5.2$ and 2 volumes of $100 \%$ ethanol at $-20^{\circ} \mathrm{C}$ ). The DNA was pelleted, dried and resuspended in water. Twenty $\mu$ L of DNA (approx. $300 \mathrm{ng}$ ) was digested with 3 units of the following enzymes AvaI, HaeIII, HhaI, MboI, MseI, MspI, NciI, and TaqI (New England Biolabs, NEB or Gibco/BRL). All digestions were conducted according to the manufactures' recommendations.

The restriction fragments were visualized on high percentage agarose gels ( 2 to $2.5 \%$ agarose in $0.5 \mathrm{X}$ TBE stained with ethidium bromide or $10 \%$ PAGE in $0.5 \% \mathrm{X}$ TBE and silver stained (BioRad Silver Staining Kit).

\section{Chromosomal telomere sequences primers}

Telomere primers from both known telomere sequences found in filamentous fungi were synthesized (Richards \& Ausubel, 1988; Pipe \& Shaw, 1997; Guzmán \& Sánchez, 1994). Telo A1, (TTAGGG) ${ }^{3}$, its complementary sequence Telo A1R, (AATCCC) $)^{3}$, and Telo B1, (TTTAGGG) ${ }^{3}$ and its complementary sequence Telo B1R (AAATCCC) ${ }^{3}$ were tested. Primers were not paired when used in these reactions. For PCR amplification of the Telo primers, Platinum Taq DNA polymerase (Gibco/BRL) with standard reaction conditions and an annealing temperature of $42{ }^{\circ} \mathrm{C}$ provided uniform results. Amplified fragments were visualized on $1.2 \%$ agarose gels in $0.5 \mathrm{X}$ TBE stained with ethidium bromide.

\section{Microsatellite primers}

The microsatellite primers utilized were originally described by Buscot et al. (1996), Geistlinger et al. (1997), and Longato \& Bonfante (1997), and are listed here with a new nomenclature: $\mathrm{MS}_{43} 3^{5}=(\mathrm{GTG})^{5}, \mathrm{MS} 121^{4}=(\mathrm{GACA})^{4}$; MS4342 ${ }^{4}=(\text { TGTC })^{4}$. The primers are short 3- to 5- base pair repeats that are not paired when used in these reactions. These primers work like RAPD primers, annealing to inverted repeats, thus allowing amplification of the region between the repeats. The touchdown PCR protocol was utilized to improve reproducibility of the reactions (Don et al., 1991). This protocol started with the initial annealing temperature of $65^{\circ} \mathrm{C}$ and after every two cycles, the annealing temperature was lowered by $2{ }^{\circ} \mathrm{C}$ until the final annealing temperature of $55^{\circ} \mathrm{C}$ was reached where 35 cycles were completed. Amplified fragments were visualized on $1.5 \%$ agarose gels in $0.5 \mathrm{X}$ TBE stained with ethidium bromide.

\section{Data analyses}

The determination of DNA sizes was evaluated by digital analysis of each gel with the BioRad Fluor-S MultiImager system with Multi-Analyst PC (ver. 1.1) and Quantity-One (ver. 4.0.1) software (BioRad, Hercules, CA, USA). Due to possible migration problems of the DNA fragments, a $2 \%+/$ - error was used in calculating band sizes. Gel pictures are the reverse image of the ethidium bromide stained agarose gel.

Jaccard similarity matrixes of the ITS-RFLP fragments and the other PCR products were created using the computer program SIMQUAL of NTSYS-pc version 1.70 (Applied Biostatistics, Inc.). Phenograms were produced by analyzing the matrixes with the UPGMA methods (unweighted pairedgroup method using arithmetic means), which were clustered with the computer program SAHN and visualized with the program TREE, both programs are included in NTSYS-pc.

Sequence data were acquired from GenBank and the restriction mapping analysis was done with the shareware program DNAssist ver. 1.02 (http://www.DNAssist.com/). Restriction enzyme sites were identified utilizing the latest available enzyme list from the restriction enzyme database (REBASE, http://rebase.neb.com/rebase/rebase.html).

\section{RESULTS}

\section{Identification and characterization of fungal isolates}

Analyses of nuclei number, pathogenicity and anastomosis groups were determined for each isolate. Eighteen field isolates were confirmed to be $R$. solani based upon standard characteristics and nuclei number.

Anastomosis grouping revealed that all $18 R$. solani isolates belonged to AG4 (Table 1).

\section{Pathogenicity Tests}

Utilizing the disease assessment protocol and scale of Carling et al. (1999), we evaluated $R$. solani isolates for their pathogenic potential on four different plants: tomato, bell pepper, soybean and common bean. Virulence trees for each tested plant species (Figure 1) are based on the percentage of 
the seedlings at the scale level 4 (dead seedlings) at eight days post-inoculation at $28{ }^{\circ} \mathrm{C}$. We used the scale level 4 because it represents the most severe disease state. An arbitrary rating was devised and used to construct the virulence trees based upon the following criteria: weakly virulent (W) represents 0 to $10 \%$ of the seedling at level 4 ; moderately virulent (M) represents 11 to $40 \%$ of seedlings at level 4; virulent (V) denotes 41 to $70 \%$ of the seedlings at level 4 , and highly virulent $(\mathrm{H})$ indicates 71 to $100 \%$ of the seedlings at level 4.

The isolate CARS 3 was found to be highly virulent on the four plant species tested. Two other isolates, CARS 6A and CARS 23, were virulent to highly virulent, while the pathogenicity of the other isolates varied depending on the host species.

\section{PCR analysis of the isolates}

Following the PCR amplification of the ITS1/ITS4 region, the products were digested with restriction enzymes. Four enzymes (TaqI, HhaI HaeIII and MseI) out of the eight tested revealed distinctive banding patterns (data not shown).

\begin{tabular}{|c|c|c|c|}
\hline \multirow{4}{*}{$\begin{array}{l}\text { Carioca } 80 \mathrm{SH} \\
\text { (Common Bean) }\end{array}$} & W & Б & CARS - 2, 4 \\
\hline & M & — & CARS - \\
\hline & $\mathrm{V}$ & - & CARS - 6B \\
\hline & $\mathrm{H}$ & L & $\begin{array}{r}\text { CARS }-3,5,6 \mathrm{~A}, 7,8,11,19,20,21 \\
22 \mathrm{~A}, 22 \mathrm{~B}, 22 \mathrm{C}, 22 \mathrm{D}, 23,24\end{array}$ \\
\hline \multirow{4}{*}{$\begin{array}{l}\text { EMB } 48 \\
\text { (Soybean) }\end{array}$} & W & 5 & CARS - $4,5,22 \mathrm{C}$ \\
\hline & M & - & CARS - 2, 6B, 7, 11, 19, 20, 21, 2A, \\
\hline & V & - & CARS $-8,22 \mathrm{~B}$ \\
\hline & $\mathrm{H}$ & L & CARS - 3, 6A, 23 \\
\hline \multirow{4}{*}{$\begin{array}{l}\text { Débora } \\
\text { (Tomato) }\end{array}$} & $\mathrm{W}$ & E & CARS - 4, 24 \\
\hline & M & - & CARS - $2,7,8,22 \mathrm{~A}$ \\
\hline & $\mathrm{V}$ & - & CARS - 5, 11, 19, 20, 21, 22C, 22D \\
\hline & $\mathrm{H}$ & 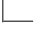 & CARS - 3, 6A, 6B, 22B, 23 \\
\hline \multirow{4}{*}{$\begin{array}{l}\text { Magali } \\
\text { (Bell Pepper) }\end{array}$} & W & - & CARS - 7 \\
\hline & M & - & CARS - 4, 6B, 22B, 24 \\
\hline & $\mathrm{V}$ & - & $\begin{array}{c}\text { CARS }-2,5,6 \mathrm{~A}, 8,11,19,20,21, \\
22 \mathrm{~A}, 22 \mathrm{C}, 22 \mathrm{D}, 23\end{array}$ \\
\hline & $\mathrm{H}$ & - & CARS - 3 \\
\hline
\end{tabular}

FIG. 1 - Virulence Trees of Rhizoctonia solani Isolates. Utilizing the disease assessment scale of Carling et al. (1999), the virulence trees for each plant species are based on the percent of the seedlings at level 4 (dead seedlings) at eight days postinoculation at $28^{\circ} \mathrm{C}$. $\mathrm{W}=$ Weakly virulent $=0$ to $10 \%$ of the seedling at level $4 ; \mathrm{M}=$ Moderately virulent $=11$ to $40 \%$ of seedlings at level $4 ; \mathrm{V}=$ Virulent $=41$ to $70 \%$ of the seedlings at level 4 ; $\mathrm{H}=$ Highly virulent $=71$ to $100 \%$ of the seedlings at level 4. This arbitrary rating was devised to assess the differences in ability of the isolates to cause disease on the various plants.
The enzymes $M s p \mathrm{I}, N c i$ I and $A v a \mathrm{I}$ did not digest the products. The enzyme $M b o$ I produced five partially digested bands in all of the isolates tested, which could not be eliminated regardless of the amount of enzyme used. Further analysis of the MseI enzyme showed that all of the tested field isolates (AG4) produced banding patterns similar to the AG4 tester strains. This banding pattern was distinct to AG4 isolates and could be used to differentiate between the subgroups AG4 HGI and AG4 HGII isolates (Figures 2A, 2B). Upon further analysis of the ITS region with the enzyme HincII, a technique established by Keijer et al. (1996), only CARS 5 was confirmed to be AG4 HGII. The ITS similarity tree separated the isolates into five genotypes, which formed three main groups at a 0.65 level of similarity (Figure 3A).

Telomere primers A1R produced 17 different PCR amplicons (Figure 4) that separated the isolates into ten genotypes that formed four main groups at a 0.35 level of similarity; (CARS 2, 57 20, 8), (CARS 6A, 6B, 11, 21, 23, 22D, 24, 19, 22A, 22C), (CARS 3 and CARS 4), and (CARS 22B) (Fig. 3B). All of the other telomere primers (TeloA1, TeloB1 and TeloB1R) failed to produce banding patterns.

The microsatellite primers MS343 and MS3121 produced 13 and 11 PCR products (Figure 5) that separated the isolates into eight and 11 genotypes on four and five main clusters, respectively (not shown). When pooled

$\mathbf{A}$

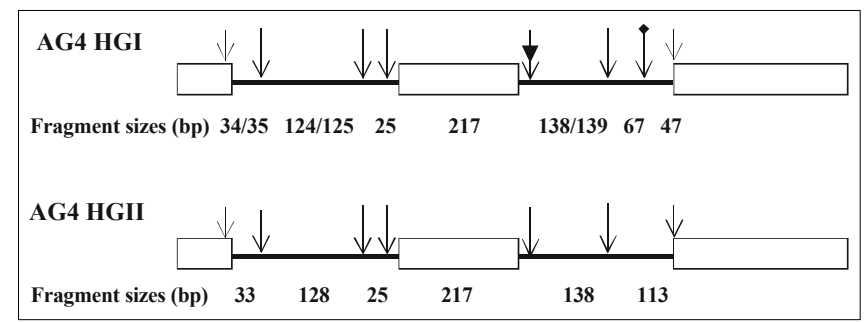

B

\begin{tabular}{|llclc|}
\hline & \multicolumn{1}{c}{ ITS1 } & $5.8 \mathrm{~S}$ & \multicolumn{1}{c|}{ ITS2 } & Number of GenBank Isolates \\
\hline AG4 HGI & $217-220 \mathrm{bp}$ & $155 \mathrm{bp}$ & $281-282 \mathrm{bp}$ & 9 \\
\multirow{2}{*}{ AG4 HGII } & $221 \mathrm{bp}$ & $155 \mathrm{bp}$ & $280 \mathrm{bp}$ & 10 \\
\hline
\end{tabular}

FIG. 2 - Summary of ITS data for AG4 HGI and HGII isolates of Rhizoctonia solani. (A) MseI restriction map of the ITS1/5.8S/ITS2 ribosomal subunit for AG4 HGI and HGII isolates of $R$. solani based on GenBank sequence data. $\downarrow$ Arrows indicate MseI sites. $\downarrow$ Arrow represents an overlapping MseI / HincII (HpaI) site that is only found in AG4 HGI isolates. $\downarrow$ Arrow indicates that this site is not present in $\mathbf{2 0 \%}$ of the sequenced isolates. The MseI banding patterns are unique to AG4 isolates and can be used to differentiate them from other anastomosis groups. (B) Sizes of the ITS1, 5.8 S and ITS2 region based upon GenBank sequence data for $R$. solani AG4 HGI and AG4 HGII isolates. 
ITS/MseI Tree

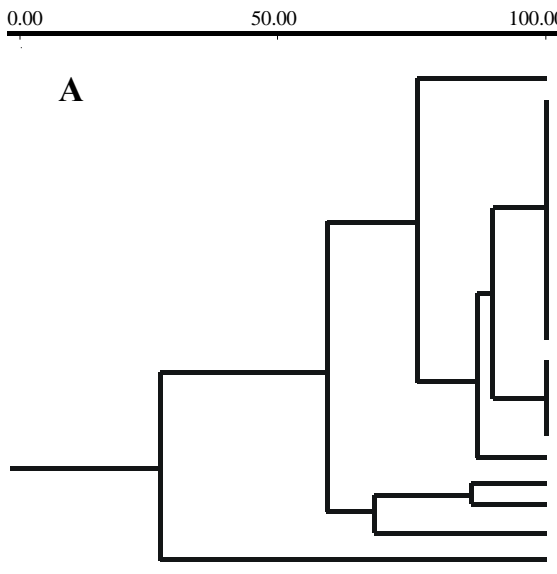

Telo1AR Tree

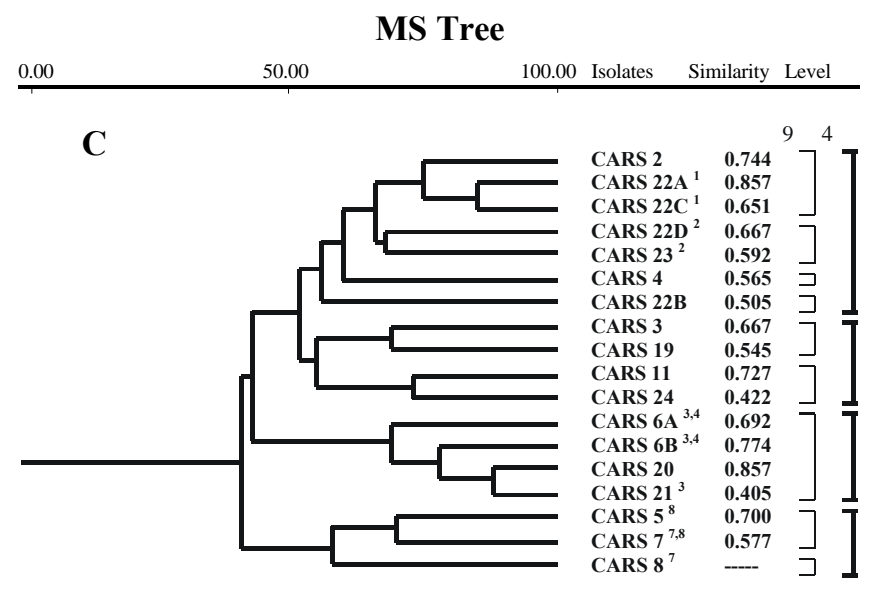

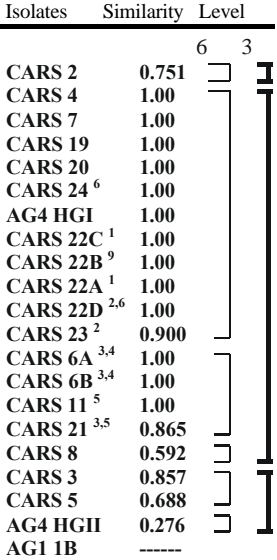

100.00 Isolates Similarity Level
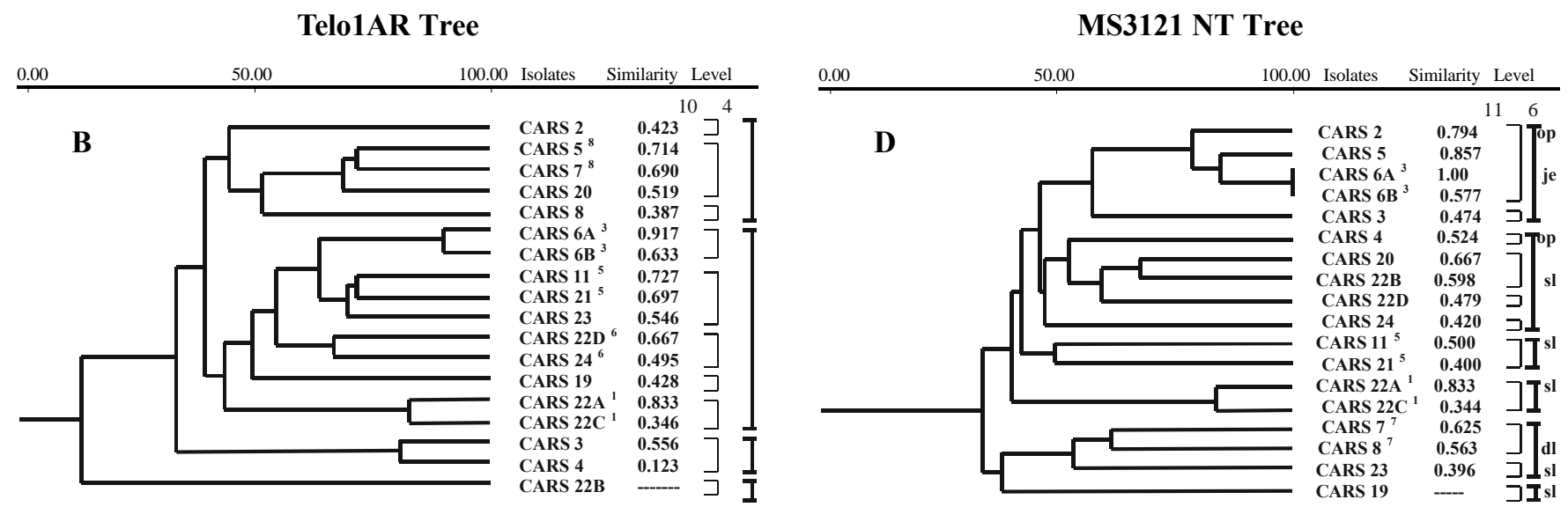

FIG. 3 - UPGMA similarity trees for the Rhizoctonia solani PCR amplicons and PCR/RFLP fragments. Op, je, sl and dl designate the sites of isolate origin within the Cunha region (Table 1). Thin brackets to the right of the UPGMA tree represent genotypes. Thick brackets to the right of the UPGMA tree designate main branches or clusters. The number of genotypes or branches is indicated above each set. Superscript numbers to the right of the isolate names represent genetically similar groupings that are supported by more than one analysis.

together, the results of MS343 and MS3121 divided the Rhizoctonia solani isolates into nine genotypes on four main groups at a similarity level of $0.50,($ CARS $2,22 \mathrm{~A}, 22 \mathrm{C}, 22 \mathrm{D}$, 23, 4, 22B) (CARS 3, 19, 11, 24) (CARS 6A, 6B, 20, 21) and (CARS 5, 7, 8) (Figure 3C). The data were pooled to expand the data set and because alone, the primer MS3121 did not support most of the genetic similarity groups established with the other primers (Figure 3D). However, when pooled, the MS tree supports most of these groups. The primer MS4342 failed to produce PCR products.

The data obtained from the microsatellite primer MS3121 used under normal (non-Touchdown) PCR conditions at an annealing temperature of $50^{\circ} \mathrm{C}$ resulted in a UPGMA clusters or branches that correlated with the different sites from which the isolates were collected (Figure 3D). Isolates from site OP clustered with isolates from site JE, while isolates from DL clustered with those from SL. The only exception was CARS 4 from site OP, which grouped with SL isolates.

\section{DISCUSSION}

Most of the Rhizoctonia-like fungal isolates recovered from infected bean plants from the Cunha region were multinucleate. All of these R. solani isolates were found to be in the anastomosis group 4 (AG4). This finding confirmed similar observations by Bolkan \& Ribeiro (1985), who found that all of the R. solani isolates from seeds or hypocotyl from beans in Brazil belonged to AG4.

The results of the pathogenicity studies clearly showed that the bean isolates of $R$. solani from Cunha could cause disease in a number of different plants and that the virulence of the isolates, in most cases, varied depending on the host. This also supports with Bolkan \& Ribeiro (1985), who found that AG4 isolates collected from different hosts from various regions of Brazil varied in their virulence on six different indicator plants. This variation in the virulence of $R$. solani isolates is well documented and has been observed by other researchers (Bolkan \& Ribeiro, 1985; Carling et al., 1999). 


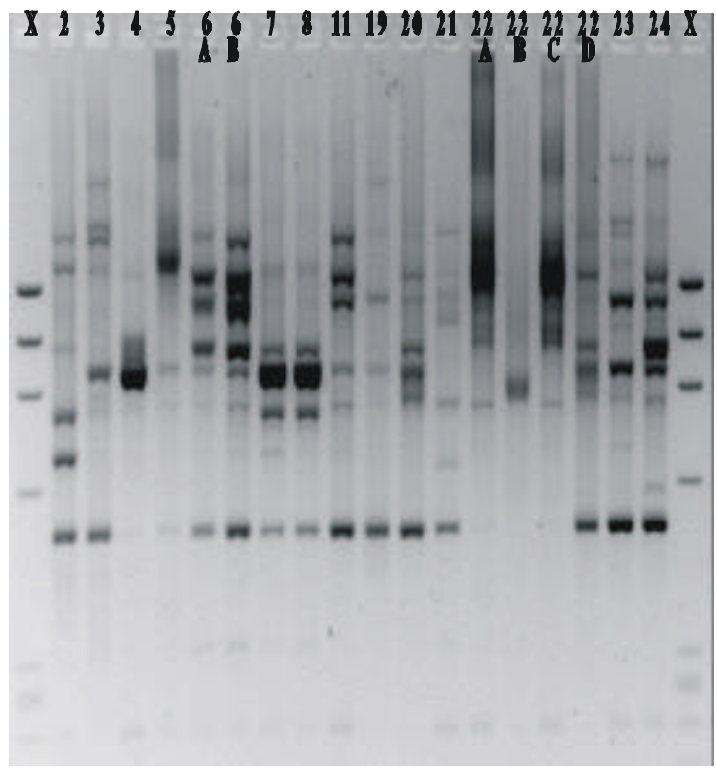

FIG. 4 - PCR products amplified with theTelo A1R primer. $\mathrm{X}=\phi X 174$ DNA HaeII Marker (Promega: size range $1,353,1,078,872,603$, not shown 310,281 , 271, 234, 194, $118 \& 72$ base pairs). Numbers refer to isolate identity (Table 1 ). The $1.2 \%$ agarose gel was run in $0.5 \mathrm{X}$ TBE buffer. Gel was digitally documented with the BioRad Fluor-S MultiImager system. The above gel is the reverse image of the ethidium bromide stained gel.

Genetically similar groups of isolates, or genotypic groups, were indicated by all of the PCR amplicons and ITS/ RFLPs used in this study, and most were verified by more than one primers or primer set (Figure 3 superscript number), which corroborates the association of these isolates and validates the use of these PCR primers for genotypic analysis.

ITS/RFLP analysis with the enzyme MseI proved to be very effective at differentiating the isolates into their anastomosis group and subgroups (Group 1 all CARS isolates except CARS3 and CARS5). These subgroups corresponded to AG4 subgroups HGI and HGII (Kuninaga \& Yokosawa, 1984) (Figure 2B). While restriction digestion of the ITS region has been used in the past with $R$. solani (Liu \& Sinclair, 1993; Keijer et al., 1996), success was limited due to the enzymes used. Sequence data derived from two independent sequencing studies conducted by Boysen et al. (1996) and Kuninaga et al. (1997) supported our findings. Furthermore, analysis of all existing AG4 ITS sequences in Genebank confirms that the enzyme MseI can specifically identify AG4 isolates from among other anastomosis groups and, in most cases, into their respective subgroups (Figures 2A, 2B). In addition, while all AG4 HGII isolates showed $100 \%$ homology within the ITS1/5.8S/ITS2 region, in 20\% of the AG4 HGI isolates a single base-pair change caused a HGII designation (Figure 2B). This was observed with the isolate CARS3, which was grouped as an HGII isolate with CARS5 based upon MseI digestion, but when digested with HincII, proved to be an

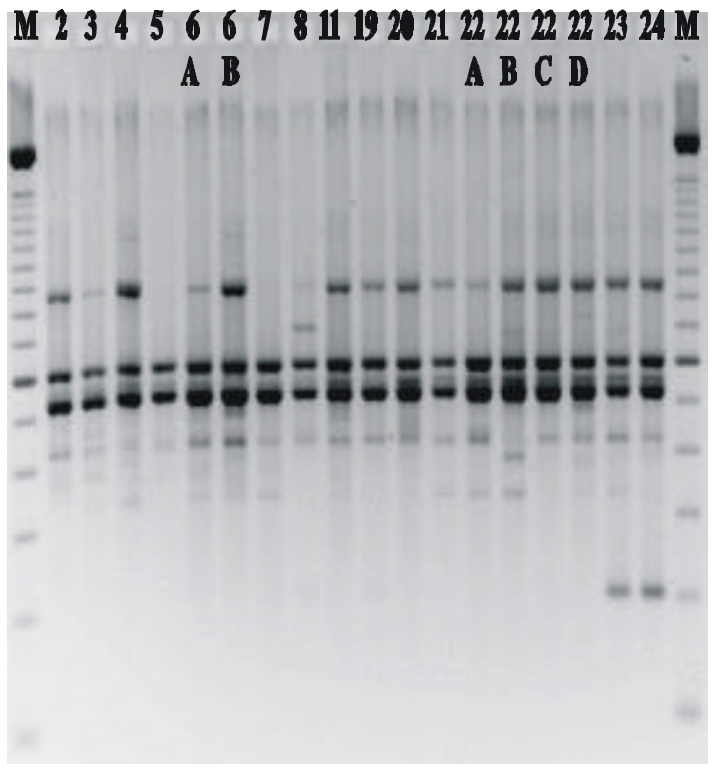

FIG. 5 - PCR amplification of the microsatellite primer MS3121 utilizing the touchdown PCR protocol. $M=100 b p$ DNA Marker (Gibco/BRL). Numbers refer to isolate identity (Table 1). The $1.5 \%$ agarose gel was run in $0.5 \mathrm{X}$ TBE buffer. Gel was digitally documented with the BioRad Fluor-S MultiImager system. The above gel is the reverse image of the ethidium bromide stained gel.

HGI isolate. Therefore, with this enzyme and method, it is of the utmost importance to confirm all AG4 HGI designations with additional HincII (Keijer et al., 1996) or HpaI (Meinhardt unpublished data) restriction digestions.

Furthermore, even though the AG4 tester strains were isolated from Arachis hypogaea L. (HGI) and Beta vulgaris L. (HGII) from Japan, they proved to be genetically very similar to our isolates (AG4), not only through ITS analysis, but also by telomere analyses (data not shown). This agrees with the studies of Vilgalys \& Gonzalez (1990) that showed AG4 isolates had very similar RFLP patterns regardless of the subgroup or origin of the isolate.

Telomere primers have been used in the past to conduct RFLP analyses of Phytophthora infestans (Mont.) de Bary (Pipe \& Shaw, 1997). This is one of the first studies, however, to directly use the telomere sequence as a PCR primer. Telomere-repeat sequences are located at the ends of the chromosomes and some linear plasmids (Powell \& Kistler, 1990), and appear to stabilize chromosomal and linear DNA and regulate cellular senescence (Counter et al., 1992).

The primer Telo A1R separated our isolates into ten genotypes that formed four main groups at 0.35 level of similarity. Several of these genotypic groups are also found in the UPGMA clusters derived from the other PCR primers used in this study (Figure 3), which validates the use of telomere primers. To ensure that the fungi used in this study were not undergoing telomere alterations (telomere 


\section{L.W. Meinhardt et al.}

shortening) that could affect results, the isolates were continuously subcultured and their DNA were analyzed at different periods $\left(5^{\text {th }}, 10^{\text {th }}, 20^{\text {th }}\right.$ etc. subculture). This analysis failed to show any differences in banding patterns when compared to the initial DNA extraction (data not shown), which suggested that $R$. solani was not undergoing any telomere alterations.

Microsatellite PCR primers are short, 3- to 5-base pair repeat sequences, which have been used to identify individuals within plants and fungal populations (Buscot et al., 1996; Caetano-Anollés \& Gresshoff, 1996; Lieckfeldt et al., 1993). All three of the tested primers were chosen because they had proven to be very useful in genetic analysis of other fungi, such as Morchella spp. (Buscot et al., 1996), glomales species, and Tuber spp. (Longato \& Bonfante, 1997). The primers MS343 and MS3121 were capable of producing polymorphic banding patterns in $R$. solani and the use of the touchdown protocol increased the reproducibility of the banding patterns. The touchdown PCR protocol reduced the total number of polymorphic bands observed for MS3121, while there was an increase in the number of bands for the MS343 primer when compared to normal PCR conditions that utilized a 50 ${ }^{\circ} \mathrm{C}$ annealing temperature.

Data from the microsatellite primers were able to identify a number of genotypes depending on whether the annealing conditions were fixed at $50{ }^{\circ} \mathrm{C}$ ( NT $=$ nontouchdown) or whether the touchdown approach was used (eight to nine for MS343 and 11 to ten for MS3121, respectively).

The touchdown MS3121 amplicons only supported one genotypic group derived from other primers. When the data from the two microsatellite primers (touchdown protocol) were pooled to form a single similarity tree (Figure 3C), all but one of the genotypic groups observed with the ITS digestions and telomere primers were supported.

One aspect of similarity analyses or genotype analysis to take into account is that PCR primers (while extremely useful) only provide a small glimpse of the total genomic make-up of the organism. Also PCR conditions can affect genotypic analysis by changing the banding profiles. Therefore, genotypes should be verified with multiple primers and analyses to ensure the authenticity of the results.

In conclusion, genetic analyses of the $18 R$. solani isolates, pathogenic to beans and taken from five sites in Cunha, revealed five to 11 different genotypes. All of the isolates belonged to the broad-host range anastomosis group 4 and demonstrated variable pathogenicity in different plant species. It is not possible at this time to say whether the degree of genotypic differences observed are normal for the region or due to the unique farming practices used in the area or to our sampling size. In addition, the genotypic differences observed could not be correlated with virulence of these $R$. solani isolates; however, they could be correlated with the AG4 anastomosis groupings and their genetic subgroups. This information will allow the monitoring of these genotypes over time, thereby giving an insight into the population dynamics of $R$. solani in the region. This should also be useful for common bean breeding programs, since these programs need to consider the genetic diversity of this pathogen, and utilize multiple, highly-virulent $R$. solani genotypes when screening for possible resistance. Further studies should answer these questions and gauge the impact of these genotypes over time.

\section{ACKNOWLEDGMENTS}

The authors would like to thank Don Carling for the AG tester strains and for permission to include them in our analyses. This study was funded by a grant from the Fundação de Amparo à Pesquisa do Estado de São Paulo (FAPESP), "Jovens Pesquisadores" Program (Project 1995/9557-8). The FAPESP program Capacitação Técnica (98/03149-3) supplied the fellowship for Nelson A. Wulff. We would like to thank the Soil Microbiology lab in the Soils Department of ESALQ/ USP for the use of their epi-fluorescent microscope.

\section{LITERATURE CITED}

BOLKAN, H.A. \& RIBEIRO, W.R.C. Anastomosis groups and pathogenicity of Rhizoctonia solani isolates from Brazil. Plant Disease 69:599-601. 1985.

BOYSEN, M., BORJA, M., DEL MORAL C., SALAZAR, O. \& RUBIO, V. Identification at strain level of Rhizoctonia solani AG4 isolates by direct sequence of asymmetric PCR products of the ITS regions. Current Genetics 29:174-181. 1996.

BUSCOT, F., WIPE, D., DI BATTISTA, C., MUNCH, J.C., BOTTON, B. \& MARTIN, F. DNA polymorphism in morels: PCR/RFLP analysis of the ribosomal DNA spacers and microsatellite-primed PCR. Mycological Research 100:63-71. 1996.

CAETANO-ANOLLÉS, G. \& GRESSHOFF, P.M. Generation of sequence signatures from DNA amplification fingerprints with mini-hairpin and microsatellite primers. Biotechniques 20:1044-1056. 1996.

CARLING, D.E. Grouping in Rhizoctonia solani by hyphal anastomosis reaction. In: Sneh, B., Jabaji-Hare, S., Neate, S., \& Dijst, G. (Eds.) Rhizoctonia solani: Taxonomy, Molecular Biology, Ecology, Pathology and Disease Control. 1996. pp. 37-47.

CARLING, D.E., KUNINAGA, S. \& LEINER R.H. Relatedness within and among intraspecific groups of Rhizoctonia solani: A comparison of grouping by anastomosis and by DNA hybridization. Phytoparasitica 16:209-210. 1988.

CARLING, D.E., POPE, E.J., BRAINARD, K.A. \& CARTER, D.A. Characterization of mycorrhizal isolates of Rhizoctonia solani from an orchid, including AG-12, a new anastomosis group. Phytopathology 89:942-946. 1999.

COUNTER, C.M., AVILION, A.A., LEFEUVRE, C.E., STEWART, N.G., GREIDER, C.W., HARLEY, C.B. \& BACCHETTI, S. Telomere shortening associated with chromosome instability is arrested in immortal cells which express telomerase activity. EMBO Journal 11:1921-1929. 1992.

DON, R.H., COX, P.T., WAINWRIGHT, B.J., BAKER, K. \& MATTICK, J.S. Touchdown PCR to circumvent spurious priming during gene amplification. Nucleic Acid Research 19:4008. 1991. 
Genetic analyses of Rhizoctonia solani isolates from Phaseolus vulgaris grown...

GEISTLINGER, J., MAQBOOL, S., KAISER, W.J. \& KAHL, G. Detection of microsatellite fingerprint markers and their Mendelian inheritance in Ascochyta rabiei. Mycological Research 101:1113-1121. 1997.

GUZMÁN, P.A. \& SÁNCHEZ, J.G. Characterization of telomeric regions from Ustilago maydis. Microbiology 140:551-557. 1994.

KEIJER, J., HOUTERMAN, P.M., DULlEMANS, A.M. \& KORSMAN, M.G. Heterogeneity in electrophoretic karyotype within and between anastomosis groups of Rhizoctonia solani. Mycological Research 100:789-797. 1996.

KUNINAGA, S. \& YOKOSAWA, R. DNA base sequence homology in Rhizoctonia solani Kühn. IV. Genetic relatedness within anastomsis group IV. Annals of the Phytopathological Society of Japan 50:322-330. 1984.

KUNINAGA, S., NATSUAKI, T., TAKEUCHI, T. \& YOKOSAWA, $R$. Sequence variation of the rDNA ITS regions within and between anastomosis groups in Rhizoctonia solani. Current Genetics 32:237-243. 1997.

LIECKFELDT, E., MEYER, W. \& BÖRNER, T. Rapid identification and differentiation of yeast by DNA and PCR fingerprinting. Journal of Basic Microbiology 33:413-426. 1993.

LIU, Z.L. \& SINCLAIR J.B. Differentiation of intraspecific groups within anastomosis group 1 of Rhizoctonia solani using ribosomal DNA internal transcribed spacer and isozyme comparisons. Canadian Journal of Plant Pathology 15:272-280. 1993.

LONGATO, S. \& BONFANTE, P. Molecular identification of mycorrhizal fungi by direct amplification of microsatellite regions. Mycological Research 101:425-432. 1997.
MEINHARDT, L.W., BELLATO, C.M. \& TSAI, S.M. The utilization of SYBR Green I to evaluate the nuclei number of fungal mycelia. BioTechniques. 31:42-46. 2001.

MORI, S.A. Eastern, extra Amazonian Brazil. In: Campbell, D.G. \& Hammond, H.D. (Eds.) Floristic inventory of tropical countries: The status of plant systematics, collections, and vegetation, plus recommendations for the future. New York. The New York Botanical Garden. 1989. pp. 427-454.

PARMETER, J.R. \& WHITNEY, H.S. Taxonomy and nomenclature of the imperfect state. In: J.R. Parmeter, Jr. (Ed.). Rhizoctonia solani, Biology and Pathology. Berkeley. University of California Press. 1970. pp.7-19.

PIPE, N.D. \& SHAW, D.S. Telomere-associated restriction fragment length polymorphisms in Phytophthora infestans. Molecular Plant Pathology On-line (http://www.bspp.org.uk/mppol/1997/ 1124pipe/paper.htm).

POWELL, W.A. \& KISTLER, H.C. In vivo rearrangement of foreign DNA by Fusarium oxysporum produces linear self-replicating plasmids. Journal of Bacteriology 172:3163-3171. 1990.

RICHARDS, E.J. \& AUSUBEL, F.M. Isolation of a higher eukaryotic telomere from Arabidopsis thaliana. Cell 53:127-136. 1988.

VILGALYS, R. \& GONZALEZ, D. Ribosomal DNA restriction fragment length polymorphisms in Rhizoctonia solani. Phytopathology 80:151-158. 1990.

WHITE, T.J., BRUNS, T., LEE, S., \& TAYLOR, J. Amplification and direct sequencing of fungal ribosomal RNA genes for phylogenetics. In: Innis, M.A., Gelfand, D.H., Sninsky, J.J. \& White, T.J. (Eds.). PCR protocols: a guide to methods and applications. San Diego. Academic Press. 1990. pp. $315-322$ 